\title{
Systematic literature review on product-system services using bibliometric analysis: main journals, articles, authors and keywords
}

\author{
Fernanda Hänsch Beuren, Paulo Augusto Cauchick Miguel \\ Federal University of Santa Catarina \\ e-mails: fernandahansch@yahoo.com.br; cauchick@deps.ufsc.br
}

\begin{abstract}
Companies from different industrial sectors have started offering solutions that add services to products aiming to enhance their market position. In this sense, the purpose of this paper is to carry out a systematic literature review on product-system services (PSS) by using the bibliometric analysis. PSS is being considered as a competitive opportunity for companies; it seeks to reduce the consumption of products through its use and provision of services. Deliverables from this literature research are main publications and journals, an author citation analysis, and a preliminary taxonomy to construct a theoretical map. Through this systematic literature review, a number of publications on PSS were identified in the period from 2006 to 2011. The amount of articles and the related terminology have evolved over the years with publications in different academic journals. Business models such as PSS have faced problems related to terminology and there is certain lack of consensus among academics and practitioners. This would facilitate the knowledge exchange among stakeholders as well as readers' understanding. Although there are business models on PSS, they usually emphasize the economic aspect; therefore, environmental and social aspects should be considered in future studies.
\end{abstract}

Keywords: product-service system, PSS, service offering.

\section{Introduction}

With the growth in the large scale production, there is an increase in consumption and consequently intensification of environmental problems. The increase in consumption of products has no longer been considered as a competitive strategy. Thus, companies start offering solutions aiming at increasing their market position as well as customer's satisfaction (SUNDIN, 2009; SAKAO; SANDSTRÖM; MATZEN, 2009b). One of the solutions being discussed is the design and offer of product-service systems (PSS). PSS aims to increase the competitiveness and profitability of companies and is mainly aimed at reducing the consumption of products through alternatives of product use.

In this context, this study aims to realize a review of the literature on PSS in the recent years (2006 to 2011). Through a systematic search of the literature in relevant international databases, an author citation analysis was carried out on PSS publications in recent years. This step is a continuation of the work by Hänsch Beuren, Ferreira and Cauchick Miguel (2011), where the authors performed a content analysis and identified some relevant findings on PSS.

For its development, the present study is structured as follows. Firstly, the adopted research methods are outlined. This is followed by definitions and categories of PSS, starting by how the literature has been addressing this subject. After that, the evolution of the concept of PSS is highlighted by mapping the publications considering main journals, keywords, authors, and articles. Finally, issues for future research as well as the conclusions are presented.

\section{Research methods}

The present study is categorized as a theoretical article based on a systematic literature review. It covers an analysis of articles on PSS from 2006 to 2011. For literature search the following databases were accessed: ISI/Web of Science, Scopus, Compendex and Springer Link. Those databases present the main journals related to the subject. Only journal articles were used in the analysis by identifying PSS subject in their titles, abstracts and keywords. All articles were fully read to verify their content with regard to the subject. Keywords were related to the term "product-service system" (PSS); most of them were the same as used by Baines et al. (2007): servitization, sustainability, service economy, remanufacturing, service design, productization, product substituting service, dematerialization, system solution, and functional economy, as well as some combinations. Two hundred and three articles were identified from the databases. Endnote software and SCI2 were used for retrieving, organizing and analyzing the articles. 


\section{Product Service System}

This section presents some definitions stated by various authors concerning PSS and its categories. Those definitions are used by the authors to illustrate the transition from a "pure product" to a "pure service".

\subsection{PSS definition}

The main definition of PSS and the most cited in the literature is the one given by Goedkoop et al. (1999). The authors consider PSS as a combination of products and services in a system, which provide functionalities for the consumers and reduce the environmental impact. Mont (2002) highlights the offer of a product and system of integrated products and services which are planned aiming to reduce the environmental impact through alternative scenarios of product use. The key elements of the PSS are (GOEDKOOP et al., 1999): the product; the service, in which an activity is performed without the need of a tangible good and of the system, the combination of products, services and their relations. Most authors consider PSS a competitive proposal to satisfy the consumer's needs. Other authors stress that the PSS goes beyond this, considering the concern on sustainability through the balance between the environmental, economic and social aspects (BAINES et al., 2007).

In general, the products are developed to satisfy the needs of the consumers and can be customized to include the services. Thus, the PSS may a competitive opportunity which becomes important for changes in the consumption standards. However, this process is considered to be long since people acquire products, and, in order to get acceptance by consumers, sustainable solutions in the initial design phase are needed. Designing a product and/or a service considering its life cycle is a start to achieve better results (TUKKER; TISHNER, 2006).

The planning for the durability and the dematerialization of products with the inclusion of services are the main aspects for making the products more sustainable (VOGTLÄNDER; BREZET; HENDRIKS, 2008). The dematerialization aims at reducing the quantity of materials used in the whole product life cycle, not only in its conception, but also during its use, reutilization and recycling (LI et al., 2010). Thus, there is a trend for a more efficient development of products and services through reduction of natural resources (KESTEMONT; KERKHOVE, 2010). What is called dematerialization has been discussed in the literature and has also been used as a goal for the PSS (BAINES et al., 2007). The main objective of dematerialization is human well-being through a more efficient and more sustainable development (KESTEMONT; KERKHOVE, 2010). Waste prevention and reutilization of products are examples of that (CLEARY, 2010).

The necessities of sustainable production and consumption are more and more discussed in the literature. Thus, some companies seek to add value to their products through adding services which is a strategic resource for obtaining new relationships with the consumers (VANDERMERWE; RADA, 1988; SAKAO; SANDSTRÖM; MATZEN, 2009b). The term used for this strategy is the "servitization", which is a process of value creation through adding services to the products (BAINES; LIGHTFOOT; KAY, 2009; MARTINEZ et al., 2010). Actually, the academic community has been extensively discussing PSS, but there is no comprehensive definition on the topic yet (AURICH; MANNWEILER; SCHWEITZER, 2010). In this sense, Table 1 presents the main definitions of PSS and the most cited ones by the authors between 2006 and 2011.

Table 1. Definitions on Product-Service Systems.

\begin{tabular}{|c|l|}
\hline Authors & \multicolumn{1}{c|}{ PSS definition } \\
\hline $\begin{array}{c}\text { Mont } \\
(2002)\end{array}$ & $\begin{array}{l}\text { "A system of products, services, supporting networks and infrastructure that is designed to be: competitive, } \\
\text { satisfy customer needs and have a lower environmental impact than traditional business models". }\end{array}$ \\
\hline $\begin{array}{c}\text { Manzini and Vezzoli } \\
(2003)\end{array}$ & $\begin{array}{l}\text { "An innovation strategy, shifting the business focus from designing (and selling) physical products only, to } \\
\text { designing (and selling) a system of products and services which are jointly capable of fulfilling specific client } \\
\text { demands". }\end{array}$ \\
\hline $\begin{array}{c}\text { Brandstötter et al. } \\
(2003)\end{array}$ & $\begin{array}{l}\text { "A PSS consists of tangible products and intangible services, designed and combined so that they are } \\
\text { jointly capable of fulfilling specific customer needs. Additionally PSS tries to reach the goals of sustainable } \\
\text { development". }\end{array}$ \\
\hline $\begin{array}{c}\text { Wong } \\
\text { (2004) }\end{array}$ & $\begin{array}{l}\text { "Product Service-Systems (PSS) may be defined as a solution offered for sale that involves both a product and } \\
\text { a service element, to deliver the required functionality". }\end{array}$ \\
\hline $\begin{array}{c}\text { Baines et al. } \\
\text { (2007) }\end{array}$ & $\begin{array}{l}\text { "A PSS is an integrated product and service offering that delivers value in use. A PSS offers the opportunity } \\
\text { to decouple economic success from material consumption and hence reduce the environmental impact of } \\
\text { economic activity". }\end{array}$ \\
\hline $\begin{array}{c}\text { Goedkoop et al. } \\
(1999)\end{array}$ & $\begin{array}{l}\text { "A product service-system is a system of products, services, networks of players and supporting infrastructure } \\
\text { that continuously strives to be competitive, satisfy customer needs and have lower environmental impact than } \\
\text { traditional business models". }\end{array}$ \\
\hline
\end{tabular}




\subsection{PSS categories}

Organizations started changing strategically from the sale of products to provision of services (OLIVA; KALLENBERG, 2003; SUNDIN, 2009). This change from tangible products to products based on services is a trend which aims to add value to the business (PING; JIA, 2010). Consequently, more companies are opting for solutions which involve services. This change occurs due to the sale of products with value added by services and products servitization (SUNDIN, 2009). There is, however, a radical change for using the function of a product without necessarily having it as a property. The products provide technical functions for the consumer (AURICH; MANNWEILER; SCHWEITZER, 2010), while the services ensure the availability of these functions (MAUSSANG; ZWOLINSKI; BRISSAUD, 2009). Thus, given the displacement of the economy based on purchasing products to the economy based on their use, there is a change (Figure 1) from the pure product to the pure service and, when having both product and services in a unique offer, this is known as PSS (TUKKER, 2004). Figure 1 is one of the most used graphical representations of this concept.

It should be stressed that the divisions of PSS are not strictly defined and may include more emphasis in the product or in services. Thus, the change from pure product to pure service aims at dematerializing the use of materials offering solutions in products and services which satisfy the needs of stakeholders. Moreover, it aims to reduce the environmental impact caused by the intensive consumption of tangible products. As illustrated in Figure 1, PSS may then be classified in the following perspectives (TUKKER, 2004):

- Product-oriented: supply of products with extra services where the consumer acquires a product becoming the owner of the same and also uses services which the company offers and which add value to the product.

- Use-oriented: the use of the product is sold together with the services which add value to it. In this case, the product is the property of the company which offers its use.
- Result-oriented: the objective of this category is to offer a result or a competency for the consumer, like selling washed clothes instead of washing machines (FAN; ZHANG, 2010). In this case the product is the property of the organization where the client pays only the delivered results (BAINES et al., 2007).

A number of authors (AURICH; MANNWEILER; SCHWEITZER, 2010; GEUM; PARK, 2010; SAKAO; SANDSTRÖM; MATZEN, 2009b) consider Tukker's (2004) conceptualization. They consider this concept as the most appropriate to represent the perspectives of the PSS. Nevertheless, it seems that there is no consensus yet on the categorization of PSS and this can be further explored. Some researchers consider that the property of the products should not be on the customers and others consider that different types of services correspond to a PSS (SAKAO; PANSHEF; DÖRSAM, 2009a). Therefore, it becomes necessary to explore these categories in order to facilitate the positioning of companies in the most appropriate category.

\section{Demographics of PSS publications}

This section presents some data on PSS by doing a mapping the main journals that published the subject, considering most common keywords, main authors, and most cited articles. The growing of the PSS publications from the past six years is shown in Figure 2. Details concerning those publications are presented in the next sub-sections.

\subsection{Main journals}

A diversity of journals where PSS subject is published was identified ( 105 journal titles). Since the list is extensive, Table 2 shows the top fourteen (up to $2.8 \%$ of total articles). The Journal of Cleaner Production has most publications on PSS (18 articles). In 2006, the JCP published a special edition, contributing for this result, but the journal has not published many articles on PSS in recent years with no article in 2009 and 2010 and only two in 2011. The following journals with most publications are the Journal of Manufacturing Technology Management and the Computer Integrated Manufacturing Systems, both with the same

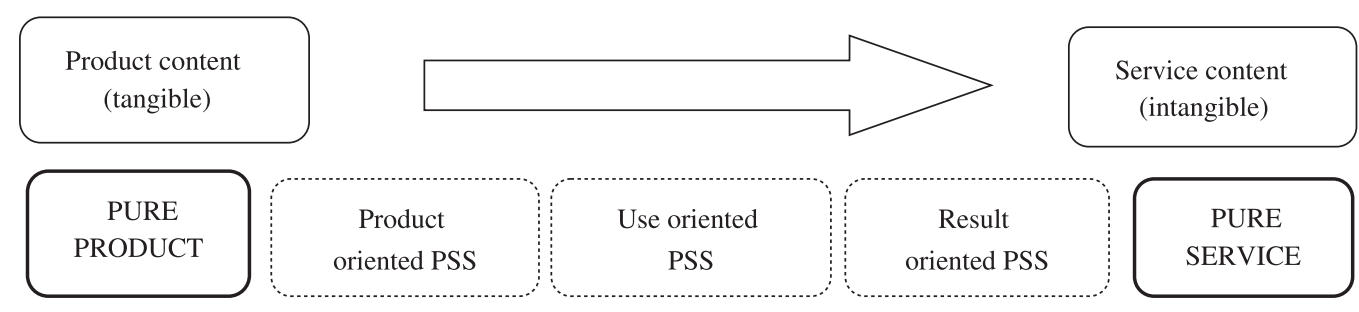

Figure 1. Main categories of the PSS (TUKKER, 2004). 
number of publications (14 articles). All publications in the JMTM and in the CIMS were issued in the past three years. IJAMT, CIRP JMST and IJIMS have published in the subject from past four years (2008-2011). Thus, it is evident in Table 2 that the JCP has the largest number of publications but not as current as the other journals.

\subsection{Main keywords}

A number of studies on PSS have been published and other terms besides PSS have been used as synonym such as (GOEDKOOP et al., 1999): "servitization", "dematerialization", "sustainability", "service design" and others. An attempt to identify those terms used in the literature was done in order to verify the diversity of the

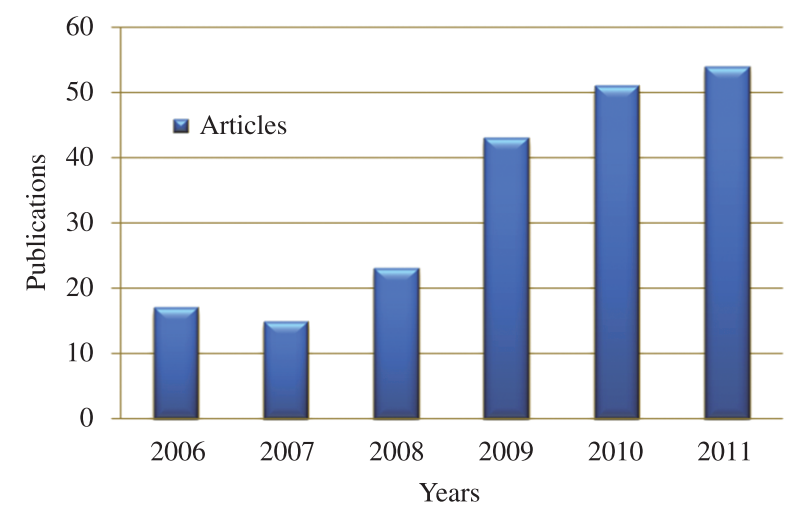

Figure 2. Evolution of publications in journals. concept. Figure 3 presents the most common terms used in the publications, mostly according to the keywords suggested by Baines et al. (2007). It shows the main keywords cited in the 203 articles. As expected, the term used most often was "product-service system", which appeared in half of the articles.

Actually, a large quantity of keywords was identified, but only the most frequently ones are presented in Figure 3. It is still noted that some of the keywords stated in section 2 (Research Methods) were not found in the present bibliographical search, such as "service economy" and "system solution".

\subsection{Main authors}

The analysis performed in the EndNote X5 software (ENDNOTE, 2011) and Sci2 Tool (SCI2 TEAM, 2009), identified the authors that have the highest number of citations alone (i.e. as a unique author) and the number of citations in joint publications among co-authors. Given a large number of articles identified in this work (203), Figure 4 highlights the main authors cited alone and those with joint publications found in the references of each article found in the references of each article.

The size of the node in the Figure 4 corresponds on how many times the author in question has been cited in the set of articles, i.e. the larger the size of the node, the more often the author has been cited. Noteworthy are the following

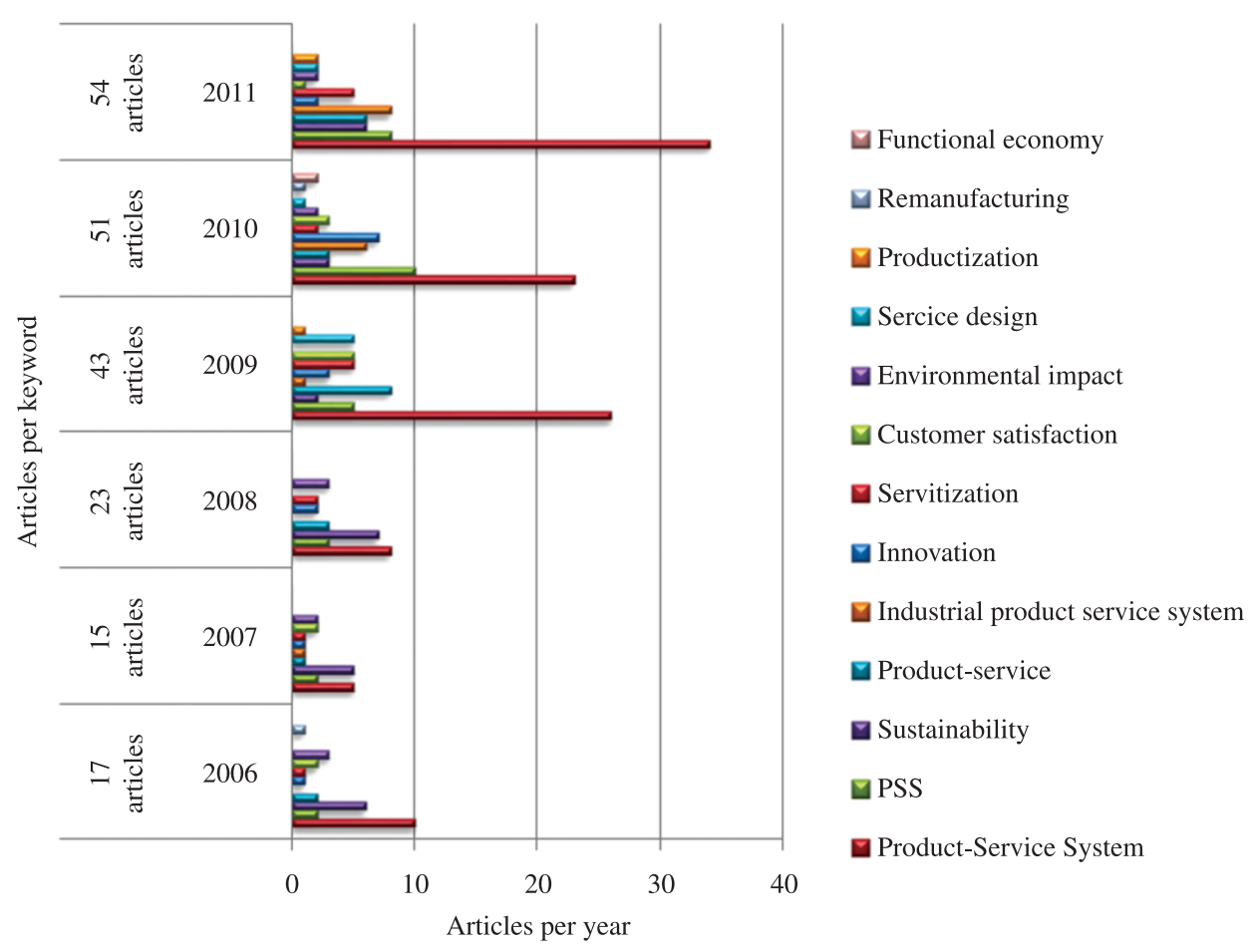

Figure 3. Main keywords related to PSS. 
Table 2. Main journals with publications on PSS ( $n=203$ articles).

\begin{tabular}{|l|c|}
\hline \multicolumn{1}{|c|}{ Academic journals } & Percentage (\%) \\
\hline Journal of Cleaner Production (JCP) & 17.1 \\
\hline Journal of Manufacturing Technology Management (JMTM) & 13.3 \\
\hline Computer Integrated Manufacturing Systems (CIMS) & 13.3 \\
\hline International Journal of Advanced Manufacturing Technology (IJAMT) & 12.4 \\
\hline CIRP Journal of Manufacturing Science and Technology (CIRP JMST) & 11.5 \\
\hline International Journal of Internet Manufacturing and Services (IJIMS) & 6.7 \\
\hline Proceedings of the Institution of Mechanical Engineers, Part B: Journal of Engineering Manufacture & 4.8 \\
\hline CIRP Annals - Manufacturing Technology & 3.8 \\
\hline International Journal of Operations and Production Management & 3.8 \\
\hline Computers and Industrial Engineering & 2.8 \\
\hline International Journal of Computer Integrated Manufacturing & 2.8 \\
\hline International Journal of Services Operations and Informatics & 2.8 \\
\hline Journal of Engineering Design & 2.8 \\
\hline ZWF Zeitschrift fuer Wirtschaftlichen Fabrikbetrieb & 2.8 \\
\hline
\end{tabular}

Note: the remaining journals have less than $2.8 \%$ of the total number of articles.

authors: Roy, R. (34 citations) and Evans, S. (32 citations) as the most cited authors in 203 articles identified in this work. It should be noted that Roy, R., has a greater number of joint publications. For example Roy, R. with Shehab, E. presented 27 joint publications, with Tiwari, A. 26 joint publications and with Alcock, JR 25 joint publications. In the case Evans, S., joint publications occurred with several authors. These values can be observed in Figure 4 by the thickness of the line; the thicker the line, the greater the number of joint publications.

As can be seen, the main objective of Figure 4 was to demonstrate which authors are cited more often and especially if the authors usually develop joint publications. The results from Figure 4 are helpful to undertake studies on PSS since it may serve as a basis for future research.

Another basis for any research in this subject is to identify which authors have published more papers on PSS. Table 3 presents the authors who have the highest number of papers published between 2006 and 2011. The authors Chu, X.N. and Tiwari, A. have 9 publications in the period from the total of 203 articles identified in this work.

It can be seen in Table 3 that the Roy, R. has 7 published articles and is in the third place. However, it is observed in Figure 4 that author is the most cited among all others. Thus, while not having the greatest number of articles published, Roy, R. has a high recognition in terms of citations.

\subsection{Main articles}

The most cited article during the period of the study were "state-of-the-art in product-service systems" by Baines et al. (2007), with 50 citations from the total of 203 articles. Baines et al. (2007) offer a great contribution
Table 3. Publications per author.

\begin{tabular}{|l|c|}
\hline \multicolumn{1}{|c|}{ Authors } & Frequency \\
\hline Chu, X. N. & 9 \\
\hline Tiwari, A. & 9 \\
\hline Alcock, J. R & 8 \\
\hline Jiang, P. Y. & 8 \\
\hline Baines, T. S. & 7 \\
\hline Lightfoot, H. W. & 7 \\
\hline Roy, R. & 7 \\
\hline
\end{tabular}

Note: the remaining authors have 6 or less published articles

by making an introduction on the subject by presenting concepts, practical examples, benefits and barriers when starting a business as a PSS.

The second article was "life cycle oriented design of technical product-service systems" by Aurich, Fuchs and Wagenknecht (2006) with 37 citations. Aurich, Fuchs and Wagenknecht (2006) encompasses the life cycle of a PSS, which covers the entire system, involving products, services, infrastructure, and customer satisfaction. Thus, there are major changes in both economic performance and the environmental performance.

The third article was "developing new product service systems (PSS): methodologies and operational tools" By Morelli (2006) with 24 citations. Morelli (2006) seeks to present methodologies and tools that contribute to the development of PSS. Nevertheless, other articles have been developed exploiting these methodologies and tools, although further research is needed in this direction.

It is worthy observing from Table 4 that the majority of citations of Baines et al. (2007), Aurich, Fuchs and Wagenknecht (2006) and Morelli (2006) were done more recently in 2009, 2010 and especially in 2011. 
Table 4. Main citations within five-year period.

\begin{tabular}{|l|c|c|c|c|c|c|}
\hline \multicolumn{1}{|c|}{ Citations } & $\mathbf{2 0 0 7}$ & $\mathbf{2 0 0 8}$ & $\mathbf{2 0 0 9}$ & $\mathbf{2 0 1 0}$ & $\mathbf{2 0 1 1}$ & Total \\
\hline Baines et al. (2007) & & & 11 & 12 & 27 & 50 \\
\hline Aurich, Fuchs and Wagenknecht (2006) & 1 & & 14 & 3 & 19 & 37 \\
\hline Morelli (2006) & & 1 & 7 & 3 & 13 & 24 \\
\hline Williams (2007) & & & 7 & 2 & 7 & 16 \\
\hline Cook, Bhamra and Lemon (2006) & & & 8 & 1 & 6 & 15 \\
\hline
\end{tabular}

Note: the remaining articles have 10 or less citations.

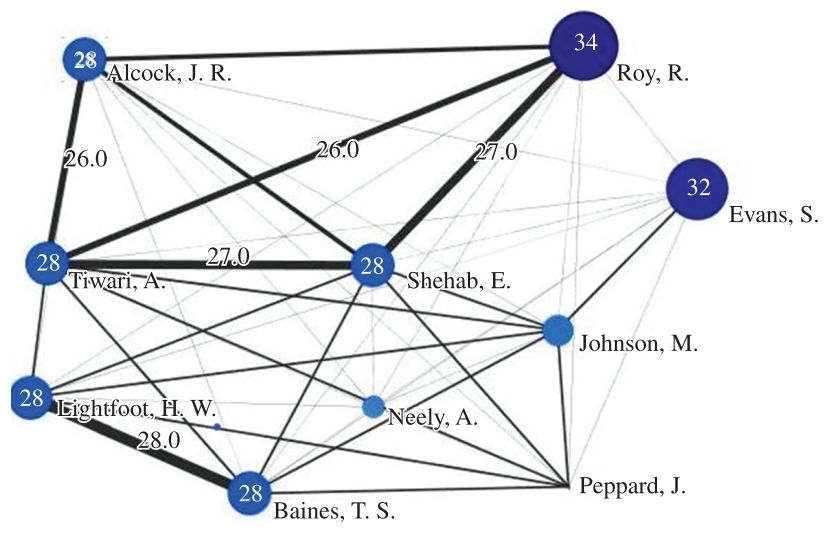

Figure 4. Net of author citations.

\section{Summary, conclusions and future research}

From a literature review of PSS between 2006 and 2011, 203 articles in relevant databases were identified. The articles were analyzed by mapping the main journals which has been publishing on the topic, the main keywords used, the main authors, and principal articles. The overall view of PSS presented in the previous sections of this paper shows that there is a growing interest in researching the subject. Several journals have published articles on PSS, with a growing number of publications year after year.

This study highlighted the diversity of keywords used in the articles; "product service system" is certainly the most used by the authors. The word "PSS" that shortens the main keyword is also present. Other terms such as "sustainability", "product-service", "industrial product served system", among others highlighted in Figure 2, should be considered when performing a literature search in the subject.

It is worth pointing out some authors who have more publications over the period from 2006 to 2011 . They have published a number of articles over the years and this should be taken into consideration when conducting research in the subject. It is also important the citations and joint publications among authors, when the work of an author is used for the development of other works. This study sought to identify key articles in the field, which will be used mainly to develop new proposals.
From the literature perspective, it can be concluded that, when performing a search on PSS, one should take into account those results. Thus, the main objective to verify the evolution of the PSS is fulfilled. Nevertheless, there are still questions about the definition, categories, benefits, barriers of PSS and this should be investigated theoretically and empirically. With the development of PSS, future research should be conducted in different contexts of PSS. The subject needs to be further explored, seeking applications in other countries, cultures, and types of businesses to contribute to the development of empirical research on the subject. Those are possibilities for further work that is intended to be carried out. Firstly, some of existing PSS empirical experiences in a developing country is going to be investigated. Then, a construction of a conceptual model based on the current literature mapping, empirical analysis, as well as a taxonomy development is also planned for future research.

\section{Acknowledgements}

The authors would like to express their gratitude to the CNPq (The Brazilian National Research Council) and CAPES for their financial support for this research project.

\section{References}

AURICH, J. C.; MANNWEILER, C.; SCHWEITZER, E. How to design and offer services successfully. CIRP Journal of Manufacturing Science and Technology, v. 2 , n. 3, p. 136-143, 2010. http://dx.doi.org/10.1016/j. cirpj.2010.03.002

AURICH, J. C.; FUCHS, C.; WAGENKNECHT, C. Life Cycle oriented design of technical Product-Service. Journal of Cleaner Production, v. 14, n. 17, p. 1480-1494, 2006. http://dx.doi.org/10.1016/j.jclepro.2006.01.019

BAINES, T. S. et al. State-of-the-art in product-service systems. Proceedings of the Institution of Mechanical Engineers, Part B: Journal of Engineering Manufacture, v. 221, n. 10, p. $1543-1552,2007$. http://dx.doi. org/10.1243/09544054JEM858

BAINES, T. S.; LIGHTFOOT, H. W.; KAY, J. M. Servitized manufacture: practical challenges of delivering integrated products and services. Proceedings of the Institution of Mechanical Engineers, Part B: Journal of Engineering 
Manufacture, v. 223, n. 9, p. 1207-1215, 2009. http://dx.doi. org/10.1243/09544054JEM1552

BRANDSTÖTTER, M. et al. IT on demand-towards an environmental conscious service system for Vienna. In: INTERNATIONAL SYMPOSIUM ON ENVIRONMENTALLY CONSCIOUS DESIGN AND INVERSE MANUFACTURING, 3., 2003, Tokyo. Proceedings... Tokyo: EcoDeNet, 2003. p. 799-802.

CLEARY, J. The incorporation of waste prevention activities into life cycle assessments of municipal solid waste management systems: methodological issues. International Journal of Life Cycle Assessment, v. 15, n. 6, p. 579-589, 2010. http://dx.doi.org/10.1007/s11367-010-0186-1

COOK, M. B.; BHAMRA, T. A.; LEMON, M. The transfer and application of Product Service Systems: from academia to UK manufacturing firms. Journal of Cleaner Production, v. 14, n. 17, p. 1455-1465, 2006. http://dx.doi.org/10.1016/j. jclepro.2006.01.018

ENDNOTE. EndNote for Windows: Bibliographies Made Easy. version X5. Thomson Reuters, 2011.

FAN, X.; ZHANG, H. Aligning Product-Service Systems with market forces. A theoretical framework. In: INTERNATIONAL CONFERENCE ON SERVICE SCIENCES - ICSS' 10, 2010, Hangzhou. Proceedings... Hangzhou, 2010. p. 110-114.

GEUM, Y.; PARK, Y. Development of Technology Roadmap for Product-Service System - TRPSS. In: IEEE INTERNATIONAL CONFERENCE ON INDUSTRIAL ENGINEERING AND ENGINEERING MANAGEMENT, 2010, Dhaka. Proceedings... Dhaka: IEEE, 2010. p. 410-414

GOEDKOOP, M. J. et al. Product Service Systems: ecological and economic basics. Dutch Ministries of Environment (VROM) and Economic Affairs (EZ), 1999.

HÄNSCH BEUREN, F.; FERREIRA, M. G. G.; CAUCHICK MIGUEL, P. A. Atualização da literatura vigente sobre sistemas produto-serviço (PSS): uma análise da produção qualificada entre 2006 e 2010. In: SIMPÓSIO DE ENGENHARIA DE PRODUÇÃO - SIMPEP, 18., 2011, Bauru. Anais... Bauru: UNESP, 2011.

KESTEMONT, B.; KERKHOVE, M. Material flow accounting of an Indian village. Biomass and Bioenergy, v. 34, n. 8 , p. 1175-1182, 2010. http://dx.doi.org/10.1016/j. biombioe.2010.03.008

LI, M. S. et al. Economy-wide material input/output and dematerialization analysis of Jilin Province (China). Environmental Monitoring and Assessment, v. 165, n. 1-4, p. 263-274, 2010. http://dx.doi.org/10.1007/ s10661-009-0943-4
MANZINI, E.; VEZOLLI, C. A strategic design approach to develop sustainable product service systems: examples taken from the 'environmentally friendly innovation' Italian prize. Journal of Cleaner Production, v. 11, n. 8, p. 851-857, 2003. http://dx.doi.org/10.1016/S09596526(02)00153-1

MARTINEZ, V. et al. Challenges in transforming manufacturing organisations into product-service providers. Journal of Manufacturing Technology Management, v. 21, n. 4, p. 449-469, 2010. http://dx.doi. org/10.1108/17410381011046571

MAUSSANG, N.; ZWOLINSKI, P.; BRISSAUD, D. Product-service system design methodology: from the PSS architecture design to the products specifications. Journal of Engineering Design, v. 20, n. 4, p. 349-366, 2009. http://dx.doi.org/10.1080/09544820903149313

MONT, O. Clarifying the Concept of Product-Service System. The Journal of Cleaner Production, v. 10, n. 3, p. 237-245, 2002. http://dx.doi.org/10.1016/S09596526(01)00039-7

MORELLI, N. Developing new Product Service Systems - PSS: methodologies and operational tools. Journal of Cleaner Production, v. 14, n. 17, p. 1495-1501, 2006. http://dx.doi. org/10.1016/j.jclepro.2006.01.023

OLIVA, R.; KALLENBERG, R. Managing the Transition from Products to Services. International Journal of Service Industry Management, v. 14, n. 2, p. 160-172, 2003. http://dx.doi.org/10.1108/09564230310474138

PING, W. L.; JIA, F. Analysis on supply chain of manufacturing enterprise product service system. In: INTERNATIONAL CONFERENCE ON EMERGENCY MANAGEMENT AND MANAGEMENT SCIENCES - ICEMMS, 2010, Beijing. Proceedings... Beijing: IEEE, 2010. p. 126-129.

SAKAO, T.; PANSHEF, V.; DÖRSAM, E. Addressing Uncertainty of PSS for Value-Chain Oriented Service Development. In: SAKAO, T.; LINDAHL, M. (Eds.). Introduction to Product/Service-System Design. London: Springer, 2009a. p. 137-157. http://dx.doi.org/10.1007/9781-84882-909-1_7

SAKAO, T.; SANDSTRÖM, G. Ö.; MATZEN, D. Framing research for service orientation of manufacturers through PSS approaches. Journal of Manufacturing Technology Management, v. 20, n. 5, p. 754-778, 2009b. http://dx.doi. org/10.1108/17410380910961082

SCI2 TEAM. Science of Science (Sci2) Tool. Indiana University; SciTech Strategies, 2009.

SUNDIN, E. Life-Cycle Perspectives of Product/ServiceSystems: in design theory. In: SAKAO, T.; LINDAHL, M. (Eds.). Introduction to Product/Service-System Design. London: Springer, 2009. p. 31-49. http://dx.doi. org/10.1007/978-1-84882-909-1_2 
TUKKER, A. Eight types of product-service system: eight ways to sustainability? Experiences from SusProNet. Business Strategy and the Environment, v. 13, n. 4, p. 246-260, 2004. http://dx.doi.org/10.1002/bse.414

TUKKER, A.; TISCHNER, U. New business for old Europe: product service development, competitiveness and sustainability. Sheffield: Greenleaf Publishing, 2006.

VANDERMERWE, S.; RADA, J. Servitization of business: Adding value by adding services. European Management Journal, v. 6, n. 4, p. 314-324, 1988. http://dx.doi. org/10.1016/0263-2373(88)90033-3
VOGTLÄNDER, J. G.; BREZET, H. C.; HENDRIKS, C. F. Allocation in recycling systems. An integrated model for the analyses of environmental impact and market value. The International Journal of Life Cycle Assessment, v. 6, n. 6, p. 344-355, 2008.

WILLIAMS, A. Product-service systems in the automotive industry: the case of micro-factory retailing. Journal of Cleaner Production, v. 14, n. 2, p. 172-184, 2006. http://dx.doi.org/10.1016/j.jclepro.2004.09.003

WONG, M. Product Service Systems in Consumer Goods Industry. 2004. Thesis (Doctorate)-Cambridge University, Cambridge, 2004. 